\title{
A Gaussian model approach to determine the commencement, termination and length of the major growing season over the dry zone of Sri Lanka
}

\author{
Asanga D Ampitiyawatta ( $\nabla$ ada@agri.sab.ac.lk) \\ Sabaragamuwa University of Sri Lanka https://orcid.org/0000-0001-6319-8198 \\ E.P.R.H.H.W. Nilmalgoda \\ Sabaragamuwa University of Sri Lanka \\ Eranga M. Wimalasiri \\ Sabaragamuwa University of Sri Lanka
}

\section{Research Article}

Keywords: commencement, termination, Gaussian model, Sri Lanka, Maha season

Posted Date: November 10th, 2021

DOl: https://doi.org/10.21203/rs.3.rs-983901/v1

License: (c) (1) This work is licensed under a Creative Commons Attribution 4.0 International License. Read Full License

Version of Record: A version of this preprint was published at Theoretical and Applied Climatology on February 12th, 2022. See the published version at https://doi.org/10.1007/s00704-022-03964-2. 


\section{Abstract}

The commencement, termination and length of the major (Maha) growing season over the dry zone of Sri Lanka were determined using daily rainfall records from 1981 to 2019 of five meteorological stations (Anuradhapura, Polonnaruwa, Hambantota, Puttalam and Batticaloa). Cumulative percentages of daily rainfall were plotted against the time and maximum positive and maximum negative curvatures were derived as the commencement and termination dates of the season. A Gaussian model was fitted on the cumulative distribution curve in order to remove limitations in deriving maximum positive and maximum negative curvatures. The difference between commencement and termination dates were taken as the length of the growing season. Results disclosed that there is a considerable inter-annual variation of commencement and termination dates and the length of the Maha season. Mean commencement and termination dates fall in the standard week 44.04 \pm 2.61 (end of October) and $5.10 \pm 4.20$ (1st week of February). The average seasonal length is $13.7 \pm 4.24$ weeks. Terminating date acts as the key determinant of the seasonal length. Any significant $(p>0.05)$ trend could not be observed for commencement, termination and length of the season for the analyzed period in any of the locations. It can be concluded that cumulative distribution of rainy days can be successfully used to determine commencement and termination dates of the Maha season over the dry zone of Sri Lanka where a single peak rainy period is available. However, the method needs modifications, when it applies in wet zone of the country where bimodal rainfall pattern is prominent.

\section{Introduction}

Sri Lanka is located between $5^{\circ} 55^{\prime}$ and $9^{\circ} 55^{\prime} \mathrm{N}$, and between $79^{\circ} 41^{\prime}$ and $81^{\circ} 53^{\prime} \mathrm{E}$ in the Indian Ocean and occupying a landmass of $65610 \mathrm{~km}^{2}$. The central part of the country consists of highlands rising up to more than $2500 \mathrm{~m}$, called Central Highlands and most of the other parts are relatively flat with scattered rocks. As a tropical country, Sri Lanka is exposed to tropical monsoon systems and their associated winds, which are named as Southwest monsoon (SWM) and Northeast monsoon (NEM). These two monsoons predominantly govern the rainfall climate of the country, accordingly two principle monsoon seasons (SWM: from May to September and NEM: from December to February) and two inter-monsoon rainfall seasons (First Inter-monsoon; FIM: from March to April and Second Inter-monsoon; SIM: from October to December) can be recognized (Thambyahpillay 1954; Domroes 1974; Suppiah 1996). Owing to calm atmospheric conditions, dominant rainfall is the convectional type during the inter-monsoon seasons, however considerable amount of rainfall is also blessed from the tropical depressions originating in the Bay of Bengal, especially during SIM. Seasonality of monsoon rainfall and topographical diversity creates highly variable rainfall patterns over the island, both spatially and temporally. According to the annual average rainfall amount, three major climatic zones can be described as Wet Zone (annual rainfall is higher than $2500 \mathrm{~mm})$, Intermediate zone $(1750-2500 \mathrm{~mm})$ and Dry Zone (rainfall is less than $1750 \mathrm{~mm}$ ) (Fig. 1). The southwest part of Sri Lanka is comprised of Wet Zone which is directly exposed to SWM rainfalls and FIM also brings substantial rainfall. The rest of the parts of the island are comprised of the Dry Zone. The dry zone is mainly blessed by NEM and FIM rainfalls 
where SWM produces less rainfall. The difference of elevation is the main source of temperature variation at different places, whereas regional geographical features are also modifying the temperature climate. As a whole, the annual mean temperature of Sri Lanka varies between $26-28^{\circ} \mathrm{C}$ while it is between $14^{\circ}-16^{\circ} \mathrm{C}$ in the Central Highlands.

Sri Lanka, being predominantly an agricultural country, the seasonality of rainfall is very much important to the success of agriculture. Timely commencement and subsequent seasonal characteristics such as the amount of seasonal rainfall, the termination of the rainy season and length of the growing season are key determinants of the type of crop and varieties, the extent of cultivation, the success of each growing stage and finally the yield. Annual variability of rainfall makes it critical, also difficult, in the planning of planting dates under rainfed agriculture (Hussein 1987; Kinsey et al. 1998; Raes et al. 2009; Sonnadara and Jayewardene 2015). Late commencement and early termination of seasonal rainfalls cause to shrink growing seasons and significantly reduce the crop yields. Occurrence of dry spells, when the crops are at their vegetative or reproductive stages, cause to aggravate the scenario. Further, marked variability of seasonal rainfall also contributes negatively to the availability of drinking water for livestock and wildlife, natural vegetation, the health of the community etc. Since the economy of the country is highly dependent on agriculture, prior knowledge on seasonal variations of the rainfall climate, such as commencement, termination and length of the rainy season as well as dry and wet spells, is vital to boost the agricultural productivity.

The agricultural potential of the dry zone of the country is conspicuous which occupies $60 \%$ of total land with flat and fertile soils, however, seasonal variation of monsoon rainfalls, high evaporation, and lack of rainfall restrain gaining the maximum yield (Punyawardena and Kulasiri 1996). A clear bimodal rainfall distribution could be observed over the dry zone due to seasonal variation of monsoons which leads to two distinct growing seasons. The major (Maha) growing season is from September to March and minor (Yala) is from April to August (Jayawardene et al. 2005). The Northeast monsoon is prevailing during the Maha season, brings major portion of the annual rainfall of the dry zone which is adequate only for the Maha season rainfed cultivation (Jayawardene et al. 2005). The fluctuations of commencement and termination dates cause the seasonal length to shrink which further hinders the growing activities. Hence, the actual commencement, termination and the length of the growing season are important to obtain satisfactory results under rainfed agriculture.

In the past, several methods have been used to detect the commencement, termination and length of the growing seasons (llesanmi 1972a, b; Benoit 1977; Stern et al. 1981; Olaniran 1983; Holland 1986; Adejuwon et al. 1990; Omotosho 1990, 2002; Sivakumar 1990; Tadross et al. 2005; Adejuwon and Odekunle 2006; Marteau et al. 2011; Guenang and Mkankam Kamga 2012; Sonnadara and Jayewardene 2015). All of these methods have been classified into five main categories by Odekunle (2006). Accordingly, the cumulative mean rainfall model was one of the most widely used methods for determining the starting and ending days of a rainy season (Odekunle 2006). (Sivakumar 1990) has found a strong relationship between the onset date and the length of the growing season in the southern Sahelian and Sudanian climatic zones of West Africa. Stewart (1988) has analyzed rainfall records of 18 
countries in North America, Middle East, Africa and Asia and found a strong correlation between the date of onset and duration of the growing season. Based on the percentage cumulative mean rainfall model, Odekunle, (2006) has studied on the commencement (onset) and termination (retreat) dates of the rainy season in Nigeria by using both number of rainy days and the amount of daily rainfall and has concluded as both rainy days and rainfall amount are equally effective in the determination of the mean rainfall commencement and termination dates. However, Odekunle (2006) further stated that more realistic commencement and termination dates could be generated by using the number of rainy days and the process is more efficient. Recently the number of authors (Laux et al. 2008; Hachigonta et al. 2008; Ramesh Kumar et al. 2009; Mupangwa et al. 2011; Guenang and Mkankam Kamga 2012; Vellinga et al. 2013) have been successfully identified the commencement, termination and duration of the rainy/growing season by adopting various methods classified by Odekunle (2006).

Though many agronomic experiments have been conducted for the advancement of agriculture in the dry zone, less attention was paid to the detection of climatic potential in the entire region. (Punyawardena 2002) has studied the time of onset, withdrawal and the duration of the season in the north-central dry zone and Sonnadara (2015) has studied the same for the North Eastern dry zone. However, any detailed study cannot be found to cover the entire dry zone region. Therefore, the objective of the present study is to determine the commencement, termination and length of the major growing season (Maha) over the dry zone of Sri Lanka using 39 years of daily rainfall data of 5 meteorological stations. It is also expected to examine inter-annual variations of the above criteria and to find whether there is any trend of commencement and termination dates.

\section{Data And Methodology \\ 2.1 Data}

Daily observed rainfall data from 1981 to 2019 (39 years) of five meteorological stations (Anuradhapura, Polonnaruwa, Hambantota, Puttalam and Batticaloa) which cover the whole dry zone were collected from the Department of Meteorology, Sri Lanka. Selected five stations are well distributed over the dry zone and two locations (Anuradhapura and Polonnaruwa) are located mid of the country (Fig. 1) which are in major agricultural regions. Both stations are directly blessed from the Northeast monsoon. Hambantota and Puttalam are located southeast and northwest coastal belts, respectively. Due to the specific geographical location and geomorphological features of those regions, both stations are not directly exposed to Northeast monsoon as well as Southwest monsoon rainfalls. Therefore, the annual average rainfall of those stations are comparatively less than other regions of the dry zone so that long dry spells could be observed. However, agricultural importance is conspicuous. Batticaloa is located towards to eastern coastal belt and is exposed directly to the Northeast monsoon. Since Northeast monsoon is the dominant rainfall season for the dry zone, Maha is the major growing season throughout the entire dry zone. Table 1 shows locations, mean annual rainfall and estimated percentages of missing data of these stations. There was no missing data for Anuradhapura and Polonnaruwa stations for the study period. Missing data of other stations were replaced by the long-term mean daily rainfall values which were 
estimated for a particular day of the year. Fig. 1 shows the geographical locations of these stations and respective areas of the wet and dry zone of the country.

Table 1

Locations, mean annual rainfall and percentages of missing data of selected locations

\begin{tabular}{|lllll|}
\hline Station & Latitude $\left(\mathbf{N}^{\circ}\right)$ & Longitude $\left(\mathrm{E}^{\circ}\right)$ & Mean annual rainfall $(\mathrm{mm})$ & Missing data (\%) \\
\hline Anuradhapura & 8.35 & 80.38 & 1674 & 0.00 \\
\hline Polonnaruwa & 7.86 & 81.05 & 1584 & 0.00 \\
\hline Hambantota & 6.11 & 81.13 & 1021 & 3.15 \\
\hline Puttalam & 8.03 & 79.83 & 1191 & 0.40 \\
\hline Batticaloa & 7.71 & 81.69 & 1736 & 0.85 \\
\hline
\end{tabular}

\subsection{Methodology}

This study used cumulative distributions of rainy days to detect the commencement and termination of Northeast monsoons (Maha rainfalls). As shown by Odekunle (2006), both rainy days and rainfall amount could be used to generate cumulative distributions. However, use of the count of rainy days is more efficient than the rainfall amount for individual years since rainfall amounts produce unrealistic dates of onset and retreat for isolated rainfalls, which is also more common to the dry zone of Sri Lanka.

Initially, a rainy day was defined by considering a threshold value of minimum rainfall. The least available rainfall measurement was $0.1 \mathrm{~mm}$, however, this amount of rainfall could evaporate easily under the dry zone conditions (Sonnadara and Jayewardene 2015). Hence, a higher threshold value of $0.85 \mathrm{~mm} /$ day has been used by Wimalasiri et al., (2017) to define a rainy day relevant to the dry zone of Sri Lanka. Therefore, $0.85 \mathrm{~mm} /$ day was used as the threshold value in this study also, where lower is a dry day and higher is a wet day.

The rainy season, corresponding to the Northeast monsoon (Maha season), falls between two years, which spans from October to January. Hence, the calendar was shifted by six months, July 1 st as the starting day of the year, to capture the season in the middle of 365-day year. This enables easy detection of the commencement and the termination of the rainy season. After the initial preparation of the data set, the number of rainy days for 5-day intervals was calculated and followed by the computation of the cumulative percentages for those for same time intervals. Thereafter, statistical fluctuation was reduced by applying a five-point moving average filter on cumulative percentages. Then, daily intervals were derived back by using a cubic spline interpolation followed by a ten-point moving average window for further reduction of fluctuations. Since the analysis is dealing with a data set of natural phenomena, the current study proposes fitting a Gaussian Model to generalize rainfall events and detect the 
commencement and termination dates of the rainy season, as a novel step. The fitted Gaussian model on ten point moving average window as follows,

$$
Y^{\prime}=a \times e^{-\left(\frac{x-b}{c}\right)^{2}}
$$

where, $Y^{\prime}=$ ten point moving average data, $X=$ day of the year and $a, b, c$ are constants.

Gaussian model fitness was done using MATLAB, 2017 statistical software and $a, b$ and $c$ constants were calculated for 39 years separately. Fig. 2 shows the fitted Gaussian model for the Anuradhapura station using the average values for the 1981 to 2019 period. The day of the year which corresponds to the maximum of the first derivative gives the commencement whereas the minimum of the first derivative gives the termination of the rainy season (Fig. 3). The period between commencement and termination days was considered as the length of the growing season. After estimating commencement and termination dates for 39 years separately, mean commencement, termination and the mean length of the season were computed. Further, simple probability calculations were also performed to ascertain the chance of having commencement and termination in a particular year. Trends of the commencement, termination and length of the season were calculated using Mann-Kendall non-parametric trend analysis.

\section{Results And Discussion}

\subsection{Commencement and termination of Maha season}

Table 2 shows mean dates of commencement, termination and length of the Maha season together with the number of rainy days, amount of rainfall and percentage of rainfall during the Maha season for analyzed 39 years for the selected locations. Accordingly, Anuradhapura and Polonnaruwa have similar commencement and termination dates for Maha season. The estimated average commencement dates for both locations occur around the last week in October (October 29), while termination dates fall around the end of the first week in February (February 8). Maha rainfall season for Hambantota and Puttalam regions commence one week earlier than previous (approximately October 23), while the termination is nearly one month earlier (approximately January 11). Hence the length of the season (about 80 days) is shorter by one month. The average length of the Maha season for Anuradhapura and Polonnaruwa regions expands up to 100 days. In compassion to Anuradhapura and Polonnaruwa, the commencement of Maha season for Batticaloa region is delayed about one week (November 5), while termination happens similarly. The length of the season (93 days) is less than 10 days. When considering the estimated commencement and termination dates of Maha season for five locations, Anuradhapura, Polonnaruwa and Batticaloa locations show similar results, while Hambantota and Puttalam behave similarly. This is expected because Anuradhapura, Polonnaruwa and Batticaloa stations are located in the North Central and Eastern provinces of the country so that directly expose to the Northeast monsoon. It is evident that the rainfall contribution from the Northeast monsoon is about $60 \%$ (Table 2) for these three locations. Due to the marginal position of Hambantota and Puttalam areas, the contribution from 
Northeast monsoon is minimal (about $40 \%$ of total rainfall), hence both locations have the shortest seasonal length and minimum rainy days during the Maha season. Anuradhapura has the highest number of rainy days during the Maha season, nearly $50 \%$ of days of Maha season receives rainfalls. Though the seasonal length of Batticaloa is shorter by 10 days, this location also has nearly $50 \%$ wet days.

Table 2

Dates of commencement and termination, length, number of rainy days, amount of rain and percentage of rain of Maha season

\begin{tabular}{|lllllll|}
\hline Station & $\begin{array}{l}\text { Date of } \\
\text { commencement }\end{array}$ & $\begin{array}{l}\text { Date of } \\
\text { termination }\end{array}$ & $\begin{array}{l}\text { Length in } \\
\text { days }\end{array}$ & $\begin{array}{l}\text { No. of } \\
\text { Rainy Days }\end{array}$ & $\begin{array}{l}\text { Rainfall } \\
(\mathbf{m m})\end{array}$ & $\begin{array}{l}\text { \% of } \\
\text { Rain }\end{array}$ \\
\hline Anuradhapura & 29-Oct & 8-Feb & 102 & 47 & 1068.62 & 60.73 \\
\hline Polonnaruwa & 29-Oct & 9-Feb & 103 & 39 & 1030.77 & 59.50 \\
\hline Hambantota & 24-Oct & 12-Jan & 80 & 28 & 438.23 & 40.45 \\
\hline Puttalam & 22-Oct & 10-Jan & 80 & 34 & 525.88 & 42.31 \\
\hline Batticaloa & 4-Nov & 5-Feb & 93 & 43 & 1141.64 & 59.11 \\
\hline
\end{tabular}

In earlier studies, Punyawardena (2002) has identified the commencement (onset) and withdrawal dates of Maha season for Maha-llluppallama location which is very close to the Anuradhapura by using simulated weekly rainfall data for 1000 years. The method adopted to define the commencement and termination dates was based on a threshold value of $30 \mathrm{~mm}$ rainfall per week after a previously defined week (standard week). Further, it was expected to continue this criterion up to three consecutive weeks. 35th and 50th standard weeks were considered as previously defined weeks for commencement and termination, respectively. Accordingly, first occurrence of this criterion with equal or higher than $30 \mathrm{~mm}$ rainfall was considered as the commencement of the season and the first occurrence of a long dry spell with less than $30 \mathrm{~mm}$ rainfall was considered as the termination of the rainy season. The resulted commencement was the 42nd standard week which is mid-October and the 4th and 5th standard weeks were termination which is extending up to late January. In the present study, estimated commencement and termination weeks for Anuradhapura were 44th and 7th weeks, respectively (Table 03) which are two weeks later than the previous results by Punyawardena (2002). The slight difference in the results of the previous study may due to the type of data used (simulated weekly data) where the present study used observed daily data. However, the length of the season found in both studies are exactly the same which is 14 weeks. Sonnadara (2015) has done another study using 40 years (from 1961 to 2000) observed daily rainfall data for identifying commencement, termination and length of the growing season in the north-eastern coastal region of Sri Lanka. Maximum positive and maximum negative curvature of the cumulative distribution function of rainy days were identified as commencement and termination days. The findings of Sonnadara (2015) are not tally with both the present study and Punyawardena (2002). 
The commencement date of the rainy season obtained by Sonnadara (2015) was approximately 26 September (38th week) which was one month earlier than the present study while the termination date (approximately 5th January) was also earlier than nearly one month. Sonnadara (2015) has used a combination of data of all available years for deriving commencement and termination dates while the present study analyzed individual years and finally computes the average dates. The proposed Gaussian model in this paper produces a more statistically acceptable method to derive the maximum positive (commencement) and maximum negative (termination) roots of the curve. However, the length of the season seems to be similar in all three analyses.

Table 3 shows the mean and standard deviation of commencement, termination and length of the Maha season for five locations (in a weekly basis). Accordingly, the commencement and termination week and length of the Maha season of Anuradhapura and Polonnaruwa regions are the same. This is in broad agreement with the geographical location of both stations as discussed earlier. It can be expected Northeast monsoon rainfalls for these two locations from 44th standard week and it may continue up to next year 7th week. Extended seasonal length up to four months (15 weeks) is a favourable factor to be the main agricultural districts of the country. Results of Batticaloa is also on par with the Anuradhapura and Polonnaruwa results. One week late commencement and one week early termination cause to shorten the seasonal length to 13 weeks. This scenario may beneficial in selecting crop varieties, especially rice, for the Maha agricultural season. Hambantota and Puttalam have earlier commencement (43rd week) and earlier termination (next year 3rd week) in comparison to the other locations and the length of the season is also the shortest (11 weeks). Short seasonal length, lowest rainfall and least number of rainy days can be recognized as major limitations for the agriculture of these two regions.

Table 3

Mean and standard deviation of the commencement, termination and length of the Maha season (in a weekly basis)

\begin{tabular}{|llllllll|}
\hline Station & \multicolumn{2}{l}{ Commencement } & \multicolumn{2}{l|}{ Termination } & Length & \\
\hline & Week & $\begin{array}{l}\text { Standard } \\
\text { deviation }\end{array}$ & Week & $\begin{array}{l}\text { Standard } \\
\text { deviation }\end{array}$ & Weeks & $\begin{array}{l}\text { Standard } \\
\text { deviation }\end{array}$ \\
\hline Anuradhapura & 44 & 2.67 & 7 & 3.60 & 15 & 4.10 \\
\hline Polonnaruwa & 44 & 2.82 & 7 & 4.34 & 15 & 5.45 \\
\hline Hambantota & 43 & 3.02 & 3 & 3.60 & 11 & 4.41 \\
\hline Puttalam & 43 & 1.75 & 3 & 4.14 & 11 & 3.37 \\
\hline Batticaloa & 45 & 2.27 & 6 & 3.25 & 13 & 3.93 \\
\hline
\end{tabular}

Overall, the average commencement of Maha season for the dry zone falls in the standard week $44.04 \pm$ 2.61 and terminates in the standard week $5.10 \pm 4.20$. The length of the Maha season, which is the main 
crop growing season of the dry zone is $13.7 \pm 4.24$ weeks. The observed deviations (outliers) of commencement and termination dates from the average (average $\pm 2 \mathrm{SD}$ ) for the entire analysis period are $5.12 \%$ and $3.59 \%$, respectively being the accuracy of the method adopted to derive commencement and termination dates are about $95 \%$. Large deviations such as false commencement and termination may be attributed due to sudden weather changes of those particular years.

Table 4 and 5 show the probability of a week being the commencement and termination, respectively. Results of the probability analysis for the commencement week are slightly different from the average commencement week for the analysis period. The highest probability of occurrence of the commencement of Anuradhapura, Polonnaruwa and Batticaloa locations falls in the 46th week. However, the cumulative probability of 44th, 45th and 46th weeks accounts over $60 \%$ for these three locations, making a higher chance to occur the commencement of Maha season towards to end of October to the first couple of weeks in November. Since the study period is limited only to 39 years, results are not normally distributing and some unrealistic figures are appearing. Therefore, the long period should be considered in probability analysis. In Hambantota, the commencement of Maha season falls into 42nd to 43rd weeks being a probability of $35 \%$ whereas in Puttalam having a chance of $59 \%$ for commencement in 43rd and 44th weeks. It is obvious that the commencement of Maha season for the entire dry zone is not unique and it is slightly varying location wise.

Table 4

Probability of a week being the commencement of Maha season

\section{Probability of commencement}

\begin{tabular}{|llllll|}
\hline $\begin{array}{l}\text { Commencement Week } \\
\text { number }\end{array}$ & Anuradhapura & Polonnaruwa & Hambantota & Puttalam & Batticaloa \\
\hline 40 or before & 0.051 & 0.061 & 0.088 & 0.054 & 0.059 \\
\hline 41 & 0.103 & 0.030 & 0.088 & 0.108 & 0.029 \\
\hline 42 & 0.128 & 0.061 & 0.176 & 0.108 & 0.059 \\
\hline 43 & 0.000 & 0.091 & 0.176 & 0.216 & 0.088 \\
\hline 44 & 0.179 & 0.030 & 0.088 & 0.378 & 0.029 \\
\hline 45 & 0.154 & 0.242 & 0.118 & 0.081 & 0.235 \\
\hline 46 & 0.205 & 0.333 & 0.147 & 0.081 & 0.324 \\
\hline 47 or after & 0.179 & 0.152 & 0.118 & 0.000 & 0.176 \\
\hline
\end{tabular}


Table 5

Probability of a week being the termination of Maha season

\begin{tabular}{|llllll|}
\hline \multicolumn{7}{l}{ Probability of termination } & & & \\
\hline $\begin{array}{l}\text { Termination Week } \\
\text { number (Next year) }\end{array}$ & Anuradhapura & Polonnaruwa & Hambantota & Puttalam & Batticaloa \\
\hline 3 or before & 0.128 & 0.205 & 0.677 & 0.694 & 0.241 \\
\hline 4 & 0.179 & 0.128 & 0.097 & 0.111 & 0.069 \\
\hline 5 & 0.077 & 0.103 & 0.032 & 0.028 & 0.207 \\
\hline 6 & 0.077 & 0.077 & 0.065 & 0.083 & 0.241 \\
\hline 7 & 0.205 & 0.103 & 0.097 & 0.028 & 0.241 \\
\hline 8 & 0.026 & 0.103 & 0.000 & 0.000 & 0.000 \\
\hline 9 & 0.103 & 0.026 & 0.032 & 0.000 & 0.000 \\
\hline 10 or after & 0.205 & 0.256 & 0.000 & 0.056 & 0.000 \\
\hline
\end{tabular}

In contrast to probability values of commencement dates, results for termination dates are more similar to the period average. The termination of the Maha season in Anuradhapura and Polonnaruwa occurs during 7 th and 8 th standard weeks having probabilities of $23 \%$ and $20 \%$, respectively. There is about $69 \%$ probability to occur termination in Batticaloa during the 5th to 7th weeks. It is likely to occur termination in Hambantota and Puttalam in the 3rd week or before having the chance of about $67 \%$.

\subsection{Inter annual variation of termination and termination dates and length of the Maha season}

Figures 4(a) - (e) shows the variation of commencement and termination dates from 1981 to 2019 for the analyzed five stations. Accordingly, high inter-annual variation can be seen in commencement and termination dates of all analyzed locations. The variation of commencement of the Maha season in Anuradhapura and Polonnaruwa is very similar where the standard deviations (SD) are 18.6 and 19.3 days, respectively. Though Batticaloa is also showing a similar variation pattern, the resulted variation is less than in previous locations ( $S D=14.9$ days). A conspicuous commencement time cannot be seen from the results of Hambantota where the inter annual variation is very high with the standard deviation of 20.5 days. However, Puttalam shows a clear commencement time (around 22nd October) with a minimum standard deviation of 12 days, though all the seasonal characteristics (commencement, termination, length, rainfall and number of rainy days) are resembled to Hambantota, as discussed earlier. In comparison to the commencement dates, termination dates of the Maha season of all locations are highly variable, being the key determinant of the seasonal length. The standard deviation of termination dates varies between 22 and 29 days where Puttalam having the minimum standard 
deviation for the termination dates. Therefore, commencement, termination and the length of the Maha season in Puttalam is more static compared to other localities.

Figure 5(a) - (e) shows the variation of the length of Maha rainy season of five studied locations for the period from 1981 to 2019. Results show that inter annual variation of the length of Maha season of five locations are highly variable. The coefficient of variance (CV) of the length varies from $27-39 \%$. Although the mean length of the Maha season of Anuradhapura and Polonnaruwa (102 days) are similar, there is a higher variability of the inter annual seasonal length in Polonnaruwa having a $37.5 \%$ coefficient of variance. The length variation of Anuradhapura is $28.1 \%$. As discussed earlier, Puttalum has the least seasonal length variation ( $\mathrm{CV}=27.8 \%)$ while Hambantota has the highest $(\mathrm{CV}=38.6 \%)$. These results are quite interesting in regional agricultural activities in minimizing crop failures.

Generally, farmers use month or week number in agricultural decisions making at their level. Therefore, the relationship between the commencement and the length of the season was evaluated using week, instead of the days. A strong negative correlation $(p<0.0001)$ was observed between the commencement week and the length of the season (in weeks) (Fig. 6). The following equation shows the general relationship between commencement and the length of the season for the locations studied.

LS $=47.09-0.7725 \times$ OS

where LS is the growing seasonal length (in weeks) and OS is the commencement week of the season. According to Fig. 6, a shorter length of the season can be expected with the delayed commencement of the season and vice versa. This finding agrees with the previous studies conducted by Sonnadara (2015) and Punyawardena and Kulasiri (2002) on which who obtained a similar relationship for dry zone Sri Lanka.

\subsection{Trend of commencement and termination dates}

According to the non-parametric Mann-Kendall trend analysis, commencement, termination and length of the season did not show a significant $(p>0.05)$ trend during the 1981-2019 period in any of the locations studied. The trend (Kendal's tau) of commencement, termination and length of the season is shown in Table 6. Nisansala et al., (2020), who analyzed rainfall trends in Sri Lanka during 1987 - 2017 found that generally, there was no significant trend in rainfall amount in Dry Zone Sri Lanka. Further, authors reported that rainfall amount in Anuradhapura, Batticaloa, Hambantota and Puttalam did not show a significant $(p>0.05)$ trend during North East monsoon, which was covered in this study. With parallel to the rainfall amounts, the commencement, termination and length of the season did not show a clear trend. 
Table 6

Trend (Kendal's tau) of commencement and termination dates and length of the season during the 1981-2019 period.

\begin{tabular}{|llll|}
\hline Location & Commencement & Termination & Length \\
\hline Anuradhapura & -0.146 & -0.190 & -0.115 \\
\hline Polonnaruwa & -0.131 & -0.023 & -0.001 \\
\hline Hambantota & 0.073 & -0.099 & -0.112 \\
\hline Puttalam & -0.082 & 0.143 & 0.175 \\
\hline Batticaloa & -0.035 & -0.012 & 0.023 \\
\hline
\end{tabular}

\section{Conclusions}

The commencement, termination and length of the major (Maha) growing season of the dry zone of Sri Lanka were examined based on the number of rainy days from 1981 to 2019 from five weather stations; Anuradhapura, Polonnaruwa, Hambantota, Puttalam and Batticaloa. As a novel step, this study proposes to fit a Gaussian model on the cumulative distribution curve of rainy days to remove limitations in finding maximum positive and maximum negative curvatures as commencement and termination dates. The method works well when single rainy season is available with one peak.

Results revealed that the mean commencement of the main (Maha) growing season of the dry zone of Sri Lanka occurs during the 44th standard week which is towards to end of October and the mean termination of the season occurs on the 5th standard week (1st week of February). The average length of the growing season is about 14 weeks for the entire dry zone whereas it is short by nearly one month in Hambantota and Puttalam areas. Except for Hambantota and Puttalam areas, the locations which are not directly exposed to the Northeast monsoon, most of the other regions of the dry zone receive more than $1000 \mathrm{~mm}$ rainfall during the Maha growing season which is about $60 \%$ of the annual rainfall. Approximately 38 days of the Maha season are rainy days for the entire dry zone which positively affects rainfed agriculture in the zone.

There is a high inter annual variation of commencement and termination dates throughout the dry zone. In contrast with the commencement dates, termination dates are highly variable, being the key determinant of the length of the season. However, the Puttalam area which is covering the Northwestern parts of the country having more static commencement and termination dates for the Maha season. The inter annual variation of the seasonal length is also fluctuating dramatically corresponds to the location, creating a major limitation for the agricultural activities of the zone. No significant $(p>0.05)$ trend was found for commencement, termination and length of the season in the regions during the study period.

In certain years, unexpected heavy rainfalls occur at the end of the season due to a combination of Northeast monsoon and tropical depressions create difficulty in identifying a clear peak of the season. That was affected to the model fitness process and deriving perfect commencement and termination 
dates for the season so that further modifications are required to smooth the process. Further, the method could be tested in the wet zone of the country where bimodal rainfall pattern is prominent with suitable modifications.

\section{Declarations}

Conflict of Interest: The authors declare no conflict of interest

Funding Statement: The authors acknowledge the Sabaragamuwa University of Sri Lanka Research Grant for funding this research (Grant No SUSL/RG/2019/03).

Author's Contribution: This study was planned and designed by A.D. Ampitiyawatta and Eranga M. Wiamasiri. Calculations and data analysis was done by A.D. Ampitiyawatta, E.P.R.H.H.W. Nilmalgoda and Eranga M. Wiamasiri. Manuscript drafting was done by all three authors and was reviewed and modified A.D. Ampitiyawatta.

Availability of data and material: Available from the authors upon request.

Code availability: Not applicable.

Ethics approval: Not applicable.

Consent to participate: Not applicable.

Consent for publication: Not applicable.

\section{References}

1. Adejuwon JO, Balogun EE, Adejuwon SA (1990) On the annual and seasonal patterns of rainfall fluctuations in sub-saharan West Africa. Int J Climatol 10:839-848.

https://doi.org/10.1002/joc.3370100806

2. Adejuwon JO, Odekunle TO (2006) Variability and the Severity of the "Little Dry Season" in Southwestern Nigeria. J Clim 19:483-493. https://doi.org/10.1175/JCLI3642.1

3. Benoit $P$ (1977) The start of the growing season in Northern Nigeria. Agric Meteorol 18:91-99. https://doi.org/10.1016/0002-1571(77)90042-5

4. Domroes M (1974) The Agroclimate of Ceylon. franz steiner verlag, Wiesbaden

5. Guenang GM, Mkankam Kamga F (2012) Onset, retreat and length of the rainy season over Cameroon. Atmospheric Science Letters 13:120-127. https://doi.org/10.1002/asl.371

6. Hachigonta S, Reason CJC, Tadross M (2008) An analysis of onset date and rainy season duration over Zambia. Theor Appl Climatol 91:229-243. https://doi.org/10.1007/s00704-007-0306-4

7. Holland GJ (1986) Interannual Variability of the Australian Summer Monsoon at Darwin: 1952-82. Monthly Weather Review 114:594-604. https://doi.org/10.1175/1520- 
0493(1986)114<0594:IVOTAS>2.0.CO;2

8. Hussein J (1987) Agroclimatological analysis of growing season in natural regions III, IV and V of Zimbabwe. In: Cropping in the semiarid areas of Zimbabwe. Agric. Tech. and Ext. Serv./Dep. of Res. and Spec. Serv./ Deutsche Gesellschaft f r Technische Zu“sammenarbeit, Harare, Zimbabwe, pp 2589

9. llesanmi 00 (1972a) An ampirical formulation of the onset, advance and retreat of rainfall in Nigeria. J Trop Geogr 34:17-24

10. Ilesanmi $O O$ (1972b) Aspect of the precipitation climatology of the July-August rainfall minimum of southern Nigeria. J Trop Geogr 35:51-59

11. Jayawardene HKWI, Sonnadara DUJ, Jayewardene DR (2005) Spatial interpolation of weekly rainfall depth in the dry zone of Sri Lanka. Climate Res 29:223-231. https://doi.org/10.3354/cr029223

12. Kinsey B, Burger K, Gunning JW (1998) Coping with drought in Zimbabwe: Survey evidence on responses of rural households to risk. World Dev 26:89-110. https://doi.org/10.1016/S0305750X(97)00124-1

13. Laux P, Kunstmann H, Bárdossy A (2008) Predicting the regional onset of the rainy season in West Africa. Int J Climatol 28:329-342. https://doi.org/10.1002/joc.1542

14. Marteau R, Sultan B, Moron V et al (2011) The onset of the rainy season and farmers' sowing strategy for pearl millet cultivation in Southwest Niger. Agric For Meteorol 151:1356-1369. https://doi.org/10.1016/j.agrformet.2011.05.018

15. Mupangwa W, Walker S, Twomlow S (2011) Start, end and dry spells of the growing season in semiarid southern Zimbabwe. J Arid Environ 75:1097-1104.

https://doi.org/10.1016/j.jaridenv.2011.05.011

16. Nisansala WDS, Abeysingha NS, Islam A, Bandara AMKR (2020) Recent rainfall trend over Sri Lanka (1987-2017). Int J Climatol 40:3417-3435. https://doi.org/10.1002/joc.6405

17. Odekunle TO (2006) Determining rainy season onset and retreat over Nigeria from precipitation amount and number of rainy days. Theor Appl Climatol 83:193-201. https://doi.org/10.1007/s00704-005-0166-8

18. Olaniran OJ (1983) The onset of the rains and the start of the growing season in Nigeria. Nigerian Geographical Journal 26:81-88

19. Omotosho JB (1990) Onset of thunderstorms and precipitation over Northern Nigeria. Int J Climatol 10:849-860. https://doi.org/10.1002/joc.3370100807

20. Omotosho JB (2002) Synoptic meteorology: pathway to seasonal rainfall prediction for sustainable agriculture and effective water resource management in West Africa but Nigeria in particular. Journal of the Nigerian Meteorological Society 3:81-89

21. Punyawardena BVR (2002) Identification of the potential of growing season by the onset of seasonal rains: A study in the DL1 region of the north central dry zone. Journal of National Science Foundation Sri Lanka 30:13-21 
22. Punyawardena BVR, Kulasiri D (1996) On development and comparative study of two Markov models of rainfall in the dry zone of Sri Lanka

23. Raes D, Steduto P, Hsiao TC, Fereres E (2009) AquaCrop-The FAO Crop Model to Simulate Yield Response to Water: II. Main Algorithms and Software Description. Agron J 101:438-447. https://doi.org/10.2134/agronj2008.0140s

24. Ramesh Kumar MR, Sankar S, Reason C (2009) An investigation into the conditions leading to monsoon onset over Kerala. Theor Appl Climatol 95:69-82. https://doi.org/10.1007/s00704-0080376-y

25. Sivakumar MVK (1990) Exploiting rainy season potential from the onset of rains in the Sahelian zone of West Africa. Agric For Meteorol 51:321-332. https://doi.org/10.1016/0168-1923(90)90116$\mathrm{N}$

26. Sonnadara DUJ (2015) The onset, retreat and the length of growing season in the north-eastern region of Sri Lanka. Int J Climatol 35:3633-3639. https://doi.org/10.1002/joc.4237

27. Sonnadara DUJ, Jayewardene DR (2015) A Markov chain probability model to describe wet and dry patterns of weather at Colombo. Theor Appl Climatol 119:333-340. https://doi.org/10.1007/s00704014-1117-z

28. Stern RD, Dennett MD, Garbutt DJ (1981) The start of the rains in West Africa. J Climatol 1:59-68. https://doi.org/10.1002/joc.3370010107

29. Stewart JL (1988) Response Farming in Rainfed Agriculture. The WHARF Foundation Press, Davis

30. Suppiah R (1996) Spatial and Temporal Variations in the Relationships Between the Southern Oscillation Phenomenon and the Rainfall of Sri Lanka. International Journal of Climatology 16:1391-1407. https://doi.org/10.1002/(SICI)1097-0088(199612)16:12<1391::AID-JOC94>3.0.C0;2$\mathrm{X}$

31. Tadross MA, Hewitson BC, Usman MT (2005) The Interannual Variability of the Onset of the Maize Growing Season over South Africa and Zimbabwe. J Clim 18:3356-3372. https://doi.org/10.1175/JCLI3423.1

32. Thambyahpillay G (1954) The rainfall rhythm in Ceylon. University of Ceylon Review 12:224-273

33. Vellinga M, Arribas A, Graham R (2013) Seasonal forecasts for regional onset of the West African monsoon. Clim Dyn 40:3047-3070. https://doi.org/10.1007/s00382-012-1520-z

34. Wimalasiri EM, Ashfold MJ, Walker S et al (2017) The relationship between rainfall characteristics and Proso millet (Panicum miliaceum L.) cultivation in low country dry zone, Sri Lanka. Tropical Agricultural Research Extension 20:32-44

\section{Figures}




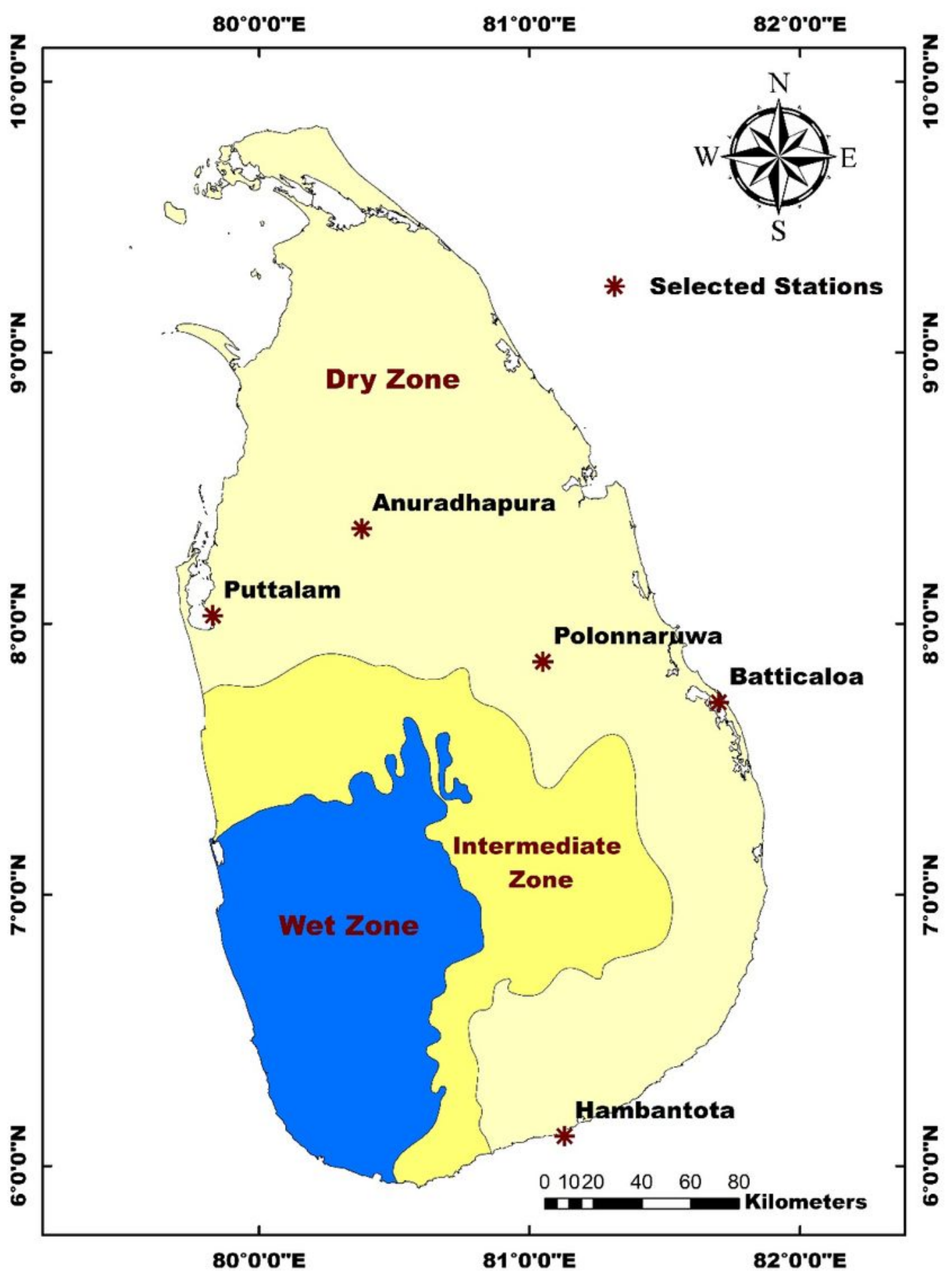

Figure 1

The geographical distribution of selected locations: Anuradhapura, Polonnaruwa, Hambantota, Puttalam and Batticaloa. The Dry Zone, Intermediate Zone and Wet Zones are also marked. 


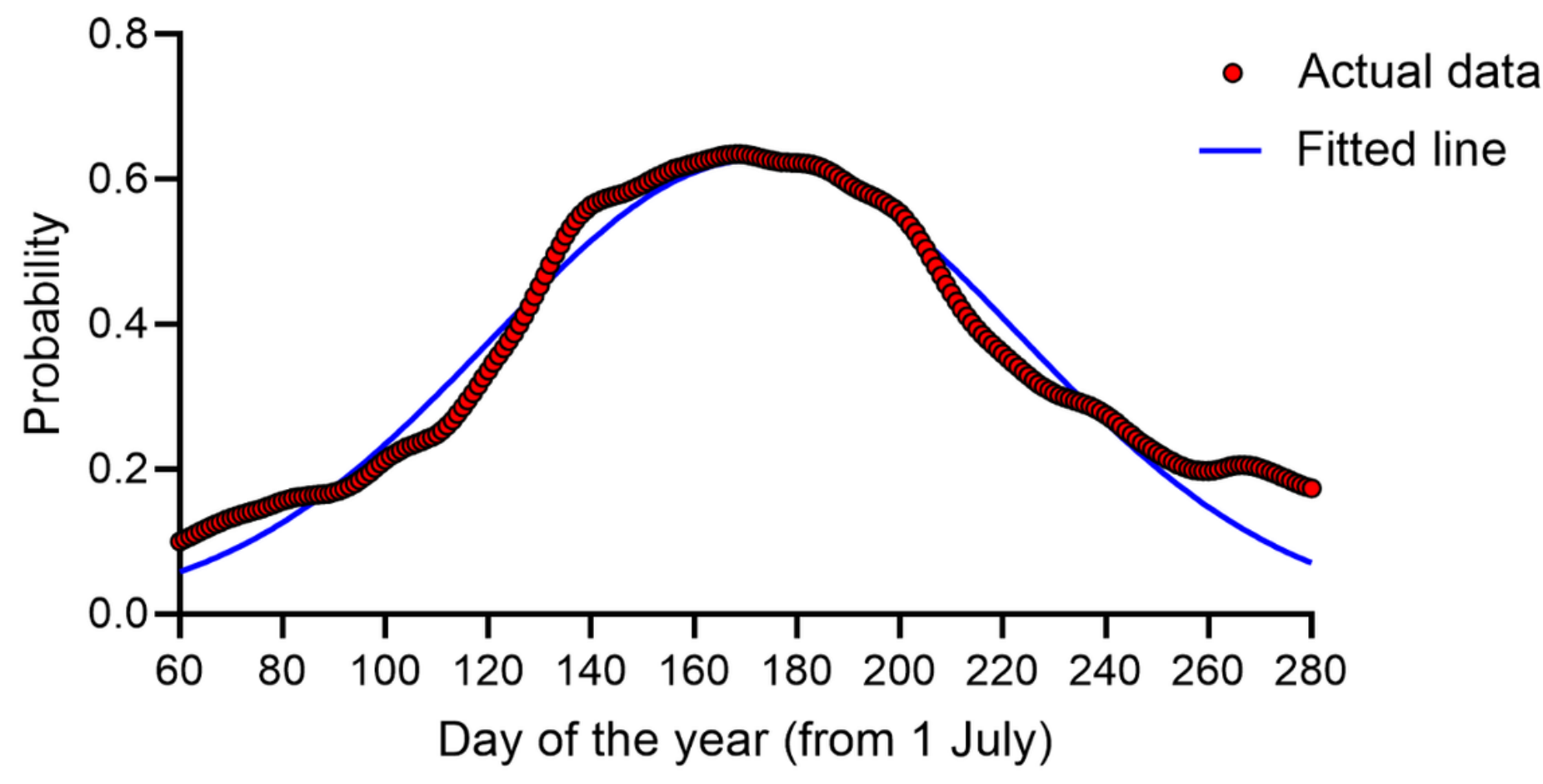

Figure 2

Fitted Gaussian model for the Anuradhapura station from 1981 to $2019 a=0.6275, b=172.3, c=72.92$ (coefficients with 95\% confidence bounds), Goodness of fit: SSE $=0.2274 . \mathrm{R} 2=0.9629, \mathrm{RMSE}=0.03389$

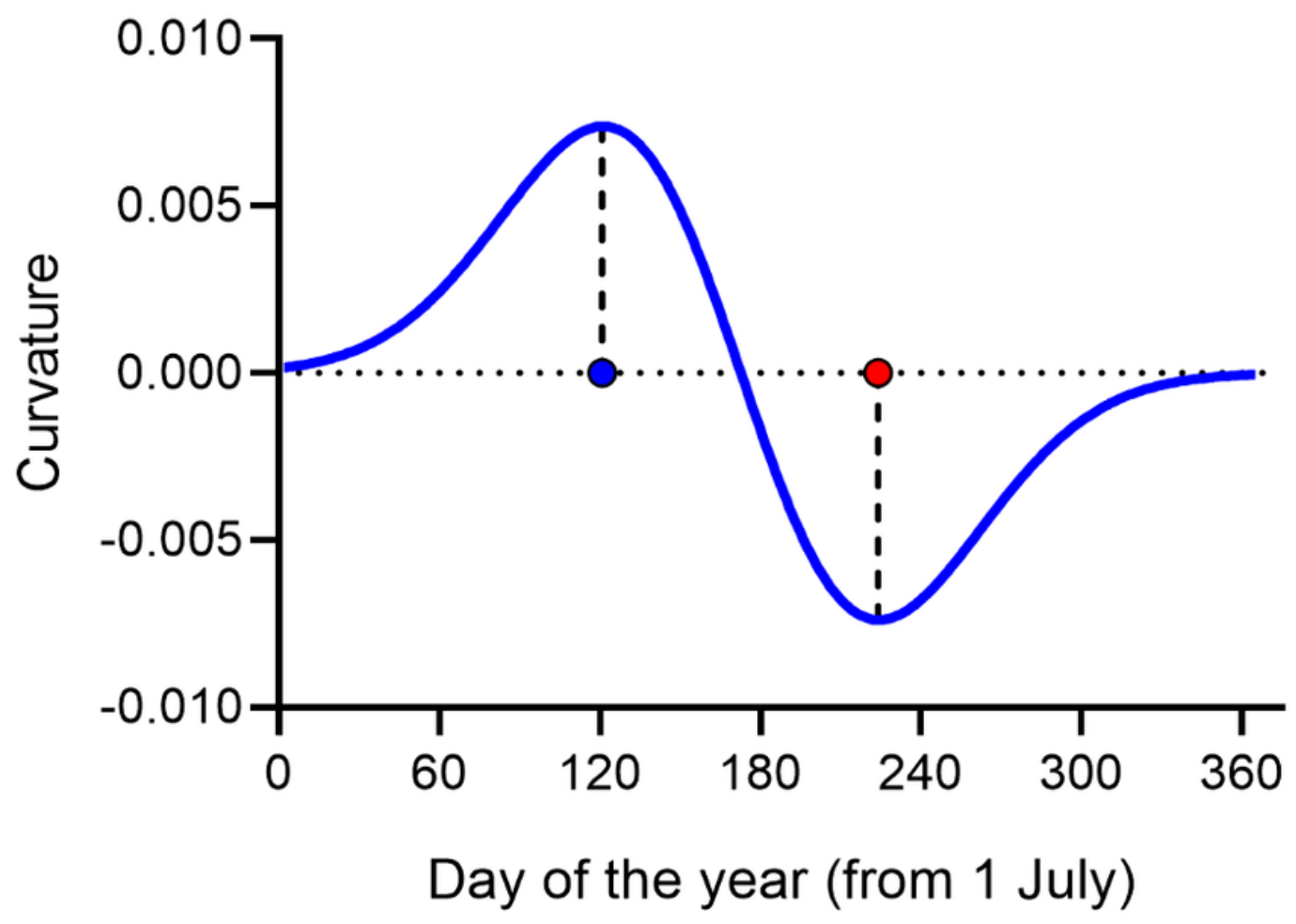

- Onset - Retreat

Figure 3 
a)

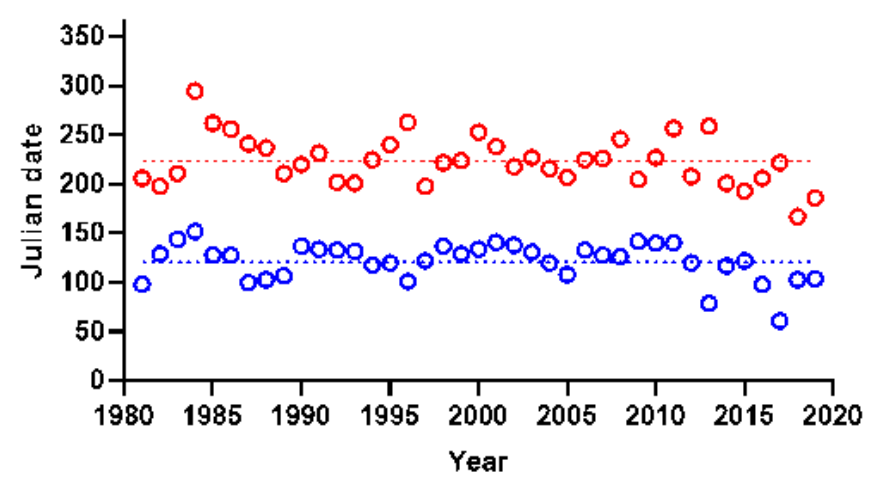

c)

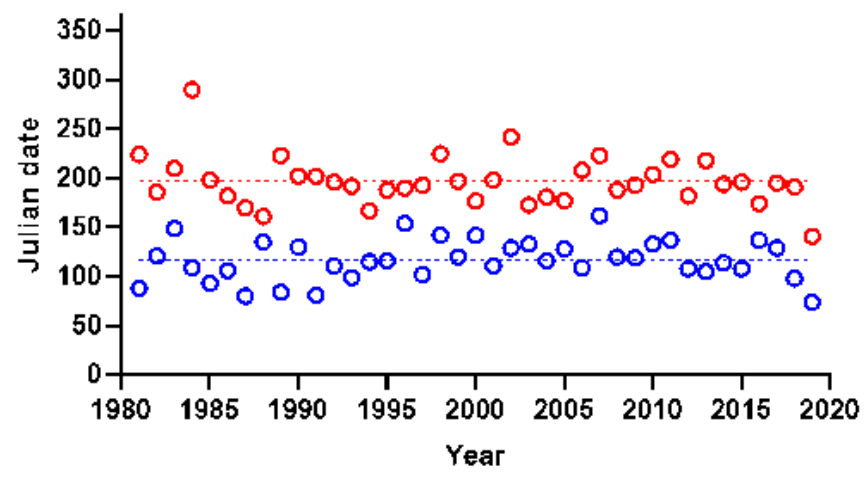

e)

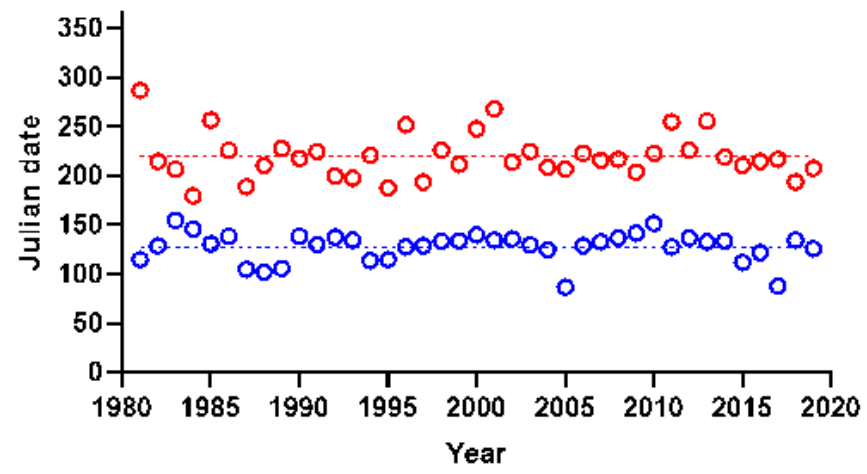

b)

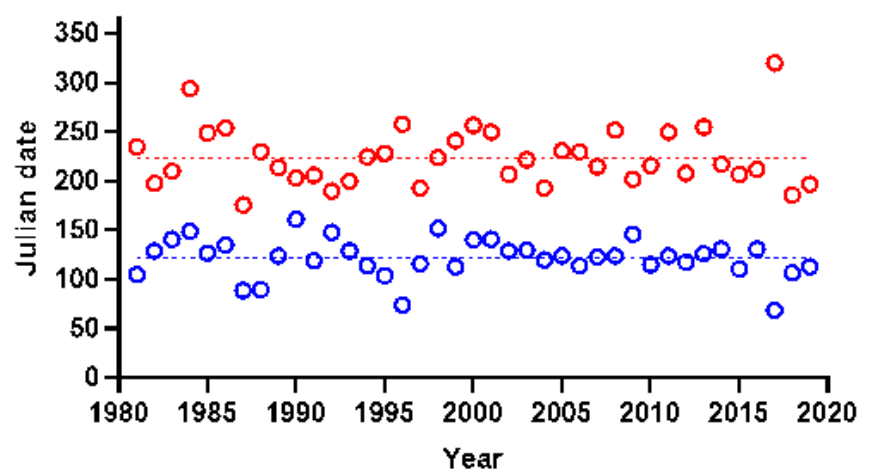

d)

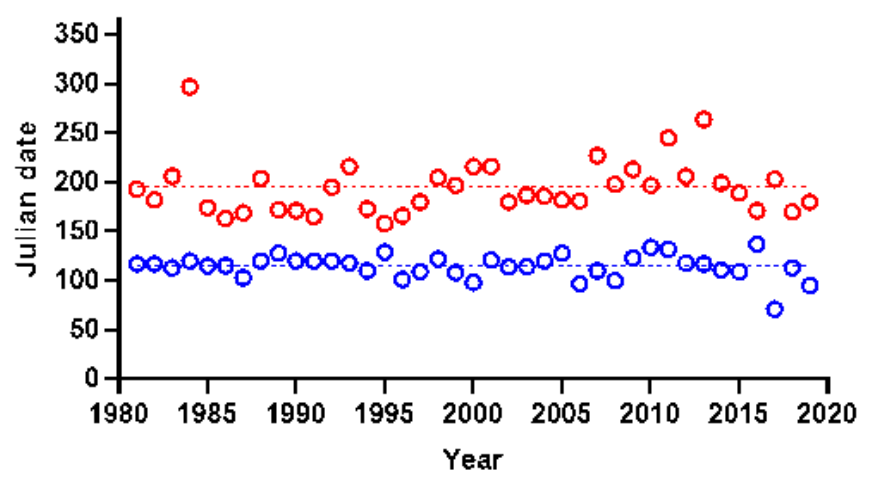

\section{Figure 4}

The variation of commencement and termination dates of (a) Anuradhapura, (b) Polonnaruwa, (c) Hambantota, (d) Puttalam and (e) Batticaloa during 1981-2019 period. The mean values of the commencement and termination dates were marked in dashed lines. 
a)

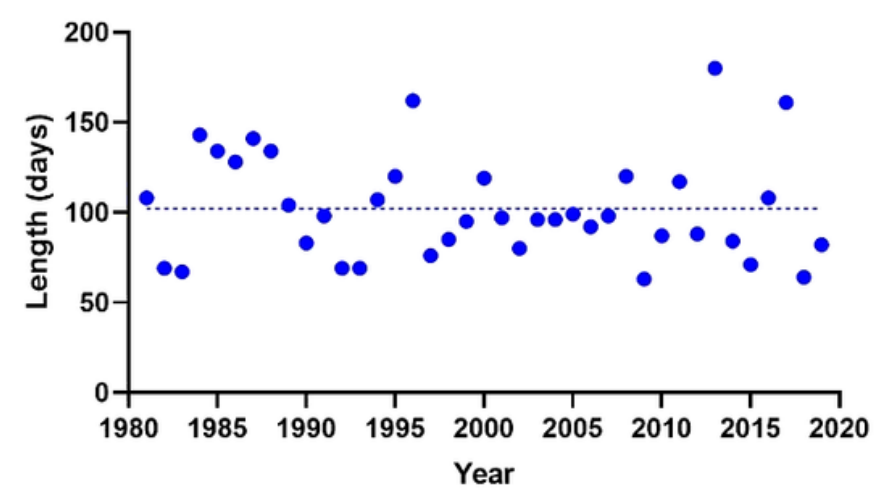

c)

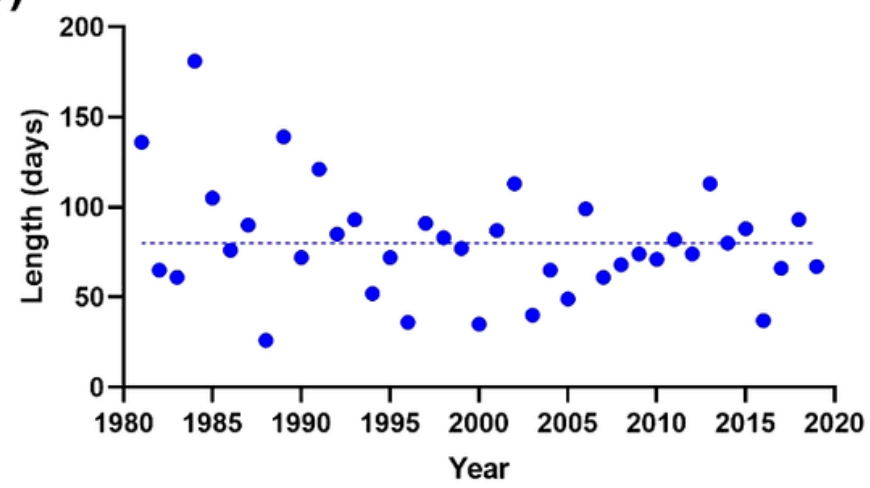

e)

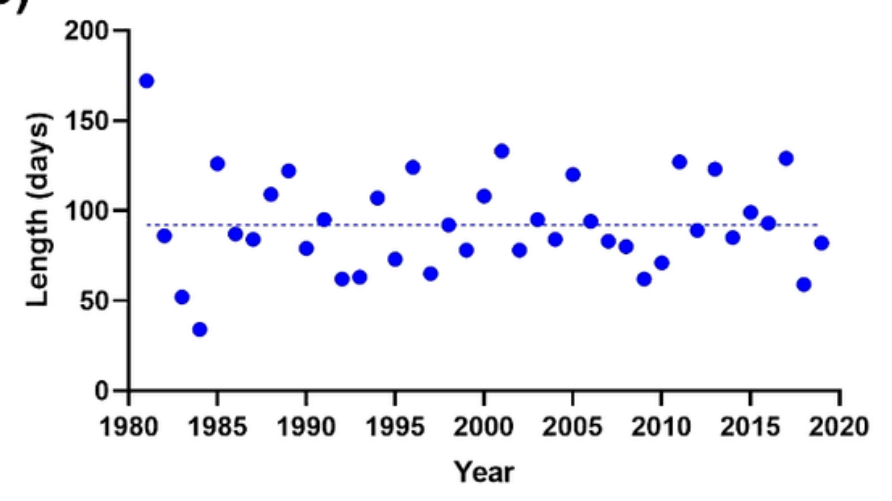

b)

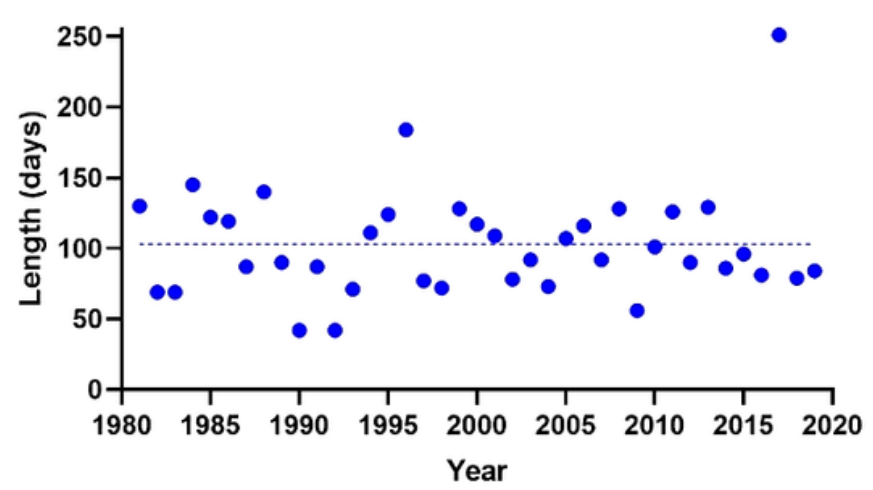

d)

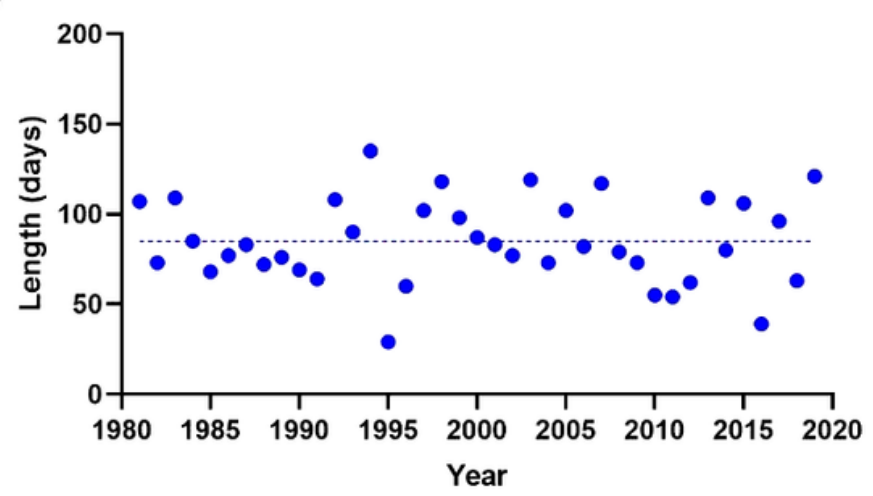

\section{Figure 5}

The variation of the length of the rainy season of (a) Anuradhapura, (b) Polonnaruwa, (c) Hambantota, (d) Puttalam and (e) Batticaloa during 1981-2019 period. 


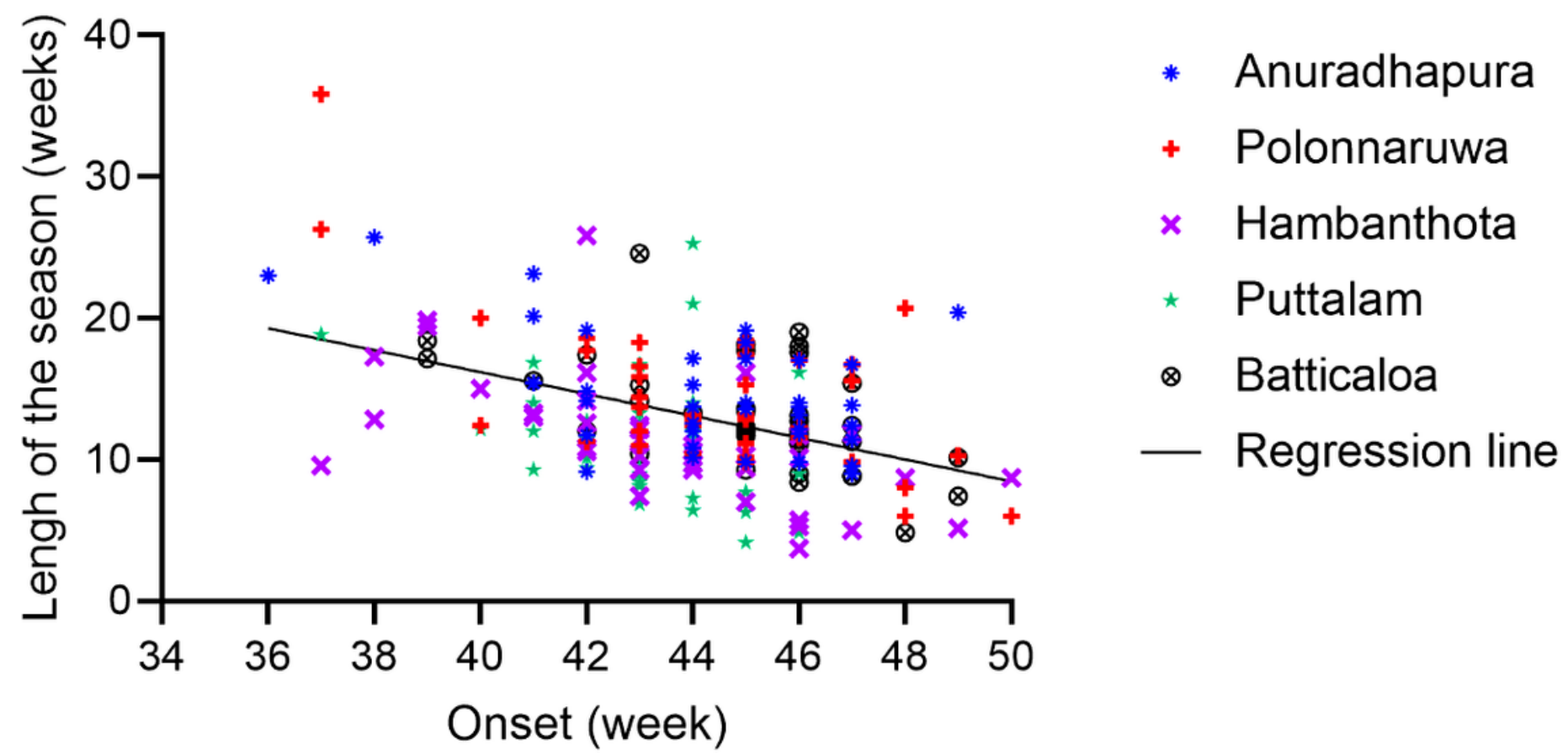

Figure 6

The relationship between commencement week and the length of the season. 